\title{
Perspective of Construction of the Lifelong education - Discussion on the Development of the MOOC
}

\author{
Chang Liu \\ Department of Economics \\ Shenyang Open University \\ Shenyang, China \\ 13898805856@139.com
}

\begin{abstract}
MOOC boom spawned on-line domestic colleges and universities curriculum online, massive open online course make a lot of people get top education opportunities at home and abroad. Along with learning to participate in the MOOC courses in the rapid expansion of the number, this model set the distance education, open education and the whole education industry on fire. The emergence of MOOC China's education system reform, play an important role in promoting the development process of higher education popularization, but online learning how to get recognition, access to credit, get the certificate is still not solve the problem. This paper will discuss the development of MOOC courses currently in our country in the perspective of construction lifelong education.
\end{abstract}

Keywords-Lifelong education; online education;Open University

\section{INTRODUCTION}

MOOC in colleges and universities in China has been developing rapidly in the short term. Tsinghua University is a model of the development of Chinese MOOC online, as of November 2014 a total of 700000 effective learners.20 classes of Peking University at the beginning of 2015 in edX and Coursera on the big date out of the half is the new curriculum. Following the Tsinghua university and Peking University announced after joining the edX platform, Shanghai Jiao Tong University and Fudan University announced one after another to join the Coursera dominated by Stanford university education platform. But the MOOC should not become a handful of colleges and universities patent, more and more colleges and universities, including the development of local colleges and universities should also be added to the MOOC. On the other hand, our country colleges and universities should establish their own MOOC platform.

\section{THE NECESSITY OF MOOC COURSES USED IN LIFELONG EDUCATION}

\section{A. The development of MOOC in China}

Different from the traditional distance education, MOOC has a short video as the basic teaching unit of the learning model based on large data, personalized learning services, relying on the network platform of interactive communication, online instant answer to problem solving, similar to the school classroom experience distinctive features. In 2013, MOOC officially entered the Chinese, in fact, as early as in 2012 October 27-28 day, Chinese society of educational development strategy of reform and development planning of professional committee of the Establishment Conference and symposium, MOOC has aroused strong concern of scholars. At the same time, the Ministry of education is also from the aspects of policy, funds, platform construction to promote the development of Chinese MOOC. In 2013 June, by the Ministry of Education Science and Technology Development Center sponsored, "Chinese education network" magazine contractors, South China University of Technology and CER NET of Southern China Area Network Center Co sponsored in 2013 the informationization of Higher Education Innovation Forum, one of the focus of the MOOC is also of concern to participants.

\section{B. The inevitable developing lifelong education}

The development of lifelong education, must take the open, flexible, inclusive, quality, life as the core concept, make full use of modern information technology, to explore the educational model, provides a more flexible learning way and accept high quality education opportunities for the majority of members of the community, so as to realize lifelong learning.

The "credit bank" is the inevitable development of lifelong education, it mainly for learners, with credits, accumulation and transformation of achievements in learning certification management center as the main function and transformation services platform. Learners in different time and professional degree education, accept the occupation training and cultural education of leisure, can accumulate credits, learners can open an account in the "bank", self-planning learning progress and learning time, will get the credit in the bank accumulated and effective life, so learning "deposit" can "cut", after conversion can be obtained when the exemption courses continue to learn; reach a certain amount can be obtained after the degree or into corresponding levels of training in college. Recently, 19 colleges and universities in Shanghai signed a cooperation agreement to build shared MOOC, establish the mechanism of mutual recognition of credits, students are not out of the school gate, can cross enrolled in courses of high quality outside the school, and obtain credit. The large-scale application of MOOC, means that it has an opportunity to create a new, more equitable education mode. 


\section{MOOC COURSE APPLIED IN THE PRACTICAL SIGNIFICANCE AND EXISTING PROBLEMS OF EDUCATION FOR THE REST OF MY LIFE}

\section{A. Practical significance}

1) The seamless learning environment for learners relaxed and happy.

The barrier-free learning space environment creation, can make the learners passive infusion to active learning and change without mechanical memory contents on-demand free retrieval resources, no matter when and where, can be relaxed and happy learning.

2) Contribute to effective sharing of education resources.

The establishment of the MOOC study can give full play to, the use of the school, family and social resources and advantage, and more close to the students for life and work. Teaching resources can be effectively shared by simple and convenient Internet communications, has realized the exchange of information with each other and complementary advantages, expand the space of education, optimize the education environment, promote the students' good behavior habits, make its comprehensive and healthy development.

\section{3) To learn practical skills.}

Learners learn by video technology is more visually specific operation process, in order to better grasp the operation skills. "Internationally, longed for class is not the most undergraduate course colleges and universities, but vocational education colleges and universities." According to the survey, American students of high school degree or above in 2014, there will be $81 \%$ of the course through the network learning; By 2020, the proportion will rise to $98 \%$.

\section{B. Has a problem}

1) The MOOC course of high production cost and low utilization rate.

In online learning, the students master the full rights of learning process, students can arrange his own study schedule, and choose the learning content, students are the real owner. This is the fundamentally different from traditional teaching. Many students study is fragmented, discontinuity, if this part is students have to master, they will take the initiative to give up, and choose to suit oneself levels of new learning content. This of course of free choice is bound to cause utilization rate is not the same.

MOOC is not simply the traditional classroom moved to online, while teaching the knowledge of the same, but still need good teachers and redesign MOOC manufacture team for the course. In addition, each section MOOC course production need to record video, editing video, add special effects, rich images, MOOC need to do a special fine courses, as well as the fragmentation. Usually each course record need two months or so. In manpower and material resources and financial resources into the production course of utilization rate is not looks so beautiful, with national Open University courses in five minutes net (http://wfz.nerc-edu.com), for example, as of March 20, 2015, preliminary statistics online courses for the 13448 classes, one of the most popular course "The Lotus Pool By Moonlight" behind the trouble" viewing for 23271 times, and there is a large part of the curriculum of the click rate is very low, there are about 1500 classes viewing for 6-10 times, had watched the number as 1-5 times course has 2800 classes, even a hundred or so course click rate is 0 .

Although the number of online education learners are tens of thousands of times of traditional education, but students in elective frequently occurs when $80 \%$ students choose $20 \%$ courses, $20 \%$ of the students choose $80 \%$ courses in this case, " The 80/20 Rule " required course producers and managers in selected course cannot without distinction, should be selective courses.

\section{2) Low MOOC course high visibility and recognition.}

Although in the past two years MOOC with unimaginable speed rapid development, but the industry recognized the MOOC certificate is still relatively low, especially in the field of employment, many of the company's human resources department is more like a traditional university experience of applicants, they believe that online course grades does not necessarily reflect the ability of the students. Watch a video and answer a few questions, fractions, the feeling is hard to say. Even after obtaining certificate of completion, is still questionable: "how do you prove to be candidates themselves rather than others for him to complete the online test? How do you prove that the test without cheating? Before these questions not clear, it's hard to believe that unit of choose and employ persons MOOC platform recommended students good enough or reliable enough." And the school experience will not only help improve the students' communication skills, interpersonal skills, broaden people's knowledge, more helps to develop students' outlook on life and values.

In spite of this, MOOC for those who have received regular college education, at the same time have a MOOC across professional certification is very welcome, effectively solve the graduates more competitive and professional obtain employment demand.

3) The MOOC course of high popularity and low efficiency.

At present, because almost all of the MOOC platform uses completely open and free registration mode, the lack of effective means of constraints, many people with a passion and interest to learn, rush registered, after a period of time, enthusiasm faded, then one after another to give up learning, leading to the registration of so many people and the completion of the course of very few people. According to statistics, MOOC course registered student attrition rate is as high as $95 \%$. Therefore, for the MOOC provider, the major problem is how to take effective measures to reduce dropout.

At the scene of the teachers and students is not the case, how to ensure the smooth implementation of the teaching behavior MOOC course, reach a certain level and make the teaching effect, how to ensure the quality of teaching? It is based on the concern of MOOC teaching quality, many of Harvard University professor called for the school on the edX platform of curriculum implementation in more strict regulation. 


\section{SIGNIFICANCE OF MOOC COURSE FOR LIFELONG EDUCATION CONSTRUCTION}

The idea of lifelong education although largely from educational circles and the whole society's approval, but in practice, the development situation of lifelong education in China is not optimistic, the reason mainly lies in education, lack of resources, can not meet the needs of all members of the society of lifelong learning. Therefore, how to scientifically and efficiently activate existing educational resources, improve resource utilization efficiency, has become the promotion of lifelong education practice, establish depth development major issue of learning society. Obviously, the MOOC with its open educational philosophy, massive education audience characteristics, will be to promote the development of lifelong education, and the formation of an important means of learning society. Education provides only need some transformation of the traditional curriculum, making it suitable for network teaching online courses, without the need for large capital investment, can achieve the purpose of a greatly expanded education capacity.

According to the basic task of lifelong education in China at the present stage, should promote the MOOC breakthrough in two aspects: the academic education and non-academic education. In the academic credentials education, the education provider should break through the current students not by learning about the MOOC to obtain the corresponding credits and degree constraints, give online courses to the corresponding credits, and issued by the national recognition of academic degree certificate to get enough credits students. It can meet the needs of learners on education, but also will greatly enhance the status of MOOC in the whole educational system and influence. In the non-academic education, community or related college can make use of MOOC platform, provide a large number of people living close to the practical needs of the people, in the life course, so as to improve the scientific culture quality of people, promote the establishment and development of lifelong education in the learning society.

\section{CONCLUSION}

In a word, the development of MOOC is rapid, even beyond imagination, however, this is only the beginning, MOOC wants to become an important part of higher education in China will still face many challenges, how to do well the MOOC still needs to policymakers to think calmly, objective and rational analysis of the new problems and new features development there, actively and steadily promote the construction of MOOC, promote the construction and development of Open University and open education, and strive to provide online courses and the highest quality personalized learning services for learners.

\section{REFERENCES}

[1] Laura Pappano. The Year of the MOOC. 2012. Form: nytimes.com/2012/11/04/education/massive open online courses are multiplying at a rapid pace.

[2] Alexander McAuley, Bonnie Stewart, George Siemens and Dave Cormier The MOOC Model for Digital Practice. pp, 10. 2010. Created through funding received by the University of Prince EdwardIsland through the Social Sciences and Humanities Research Council's" Knowledge Synthesis Grants on the Digital Economy " . From: https: //oerknowledgecloud.org.

[3] Jenny Mackness, Sui Fai John Mak, Roy Williams. The Ideals and Reality of Participating in A MOOC. Proceedings of the 7th International Conference on Networked Learning 2010. University of Lancaster, Lancaster, pp. 266-275.

[4] Nancy L. Bednar. MOOCS and Community College Distance Education. Prepared for delivery at the 2013 American Political Science Association Teaching and Learning Conference,Long Beach, California,February810,2013.Electronic copy available at: http://ssrn.com/ abstract=2207216.

[5] Dan W. Butin. What MIT Should Have Done Elearn magazine [EB/OL]. [2013 -08 -07]. https://elearnmag.acm.org/archive.cfm?aid =2263018.

[6] David Glance, Martin Forsey \& Myles Riley. The pedagogical foundations of massive open online courses[J]. First Monday,2013,18(5). 